\title{
Soil and Water Conservation in Agricultural and Forestry Systems
}

\author{
Manuel López-Vicente ${ }^{1, *(D)}$ and Gao-Lin Wu ${ }^{2,3}$ (D) \\ 1 Department of Soil and Water, Experimental Station of Aula Dei, EEAD-CSIC, 50059 Zaragoza, Spain \\ 2 State Key Laboratory of Soil Erosion and Dryland Farming on the Loess Plateau, Northwest A \& F \\ University, Yangling, Shaanxi 712100, China; wugaolin@nwsuaf.edu.cn \\ 3 Institute of Soil and Water Conservation, Chinese Academy of Sciences and Ministry of Water Resource, \\ Yangling, Shaanxi 712100, China \\ * Correspondence: mvicente@eead.csic.es or mlopezvicente@gmail.com
}

Received: 19 August 2019; Accepted: 15 September 2019; Published: 17 September 2019

\begin{abstract}
This special issue includes six articles that cover a variety of issues about the topic of soil and water conservation in agricultural systems, including the following: a bibliometric analysis of soil and water conservation in the Loess Region of China; regarding croplands, one study evaluated the influence of vegetation covers on topsoil moisture and the effect of physiographic conditions on sediment yield in Spanish vineyards; another study evaluated the influence of plant age on soil water depletion in alfalfa pastures in the Tibet Autonomous Region; in a Chinese forest plantation, the effect of plant age and species on soil bulk density and $\mathrm{pH}$ was evaluated, and the most suitable afforestation species and stand age recommended to harvest maximum benefits were determined; regarding water pollution, a study evaluated soil water dynamics during two fallow years and three barley crop seasons in Spain and estimated the effect of the applied fertilizer (slurries or minerals) on nitrate leaching; and finally, another study identified the key information, including heavy metals, for water conservation in the border areas of the Syr Darya River in Kazakhstan. The proper use of soil and water resources is necessary to ensure the future well-being of humans and of the environment.
\end{abstract}

Keywords: bibliometric analysis; soil erosion; soil water content; cover crop; vineyard; alfalfa; tree plantation; fallow system; nitrate leaching; heavy metals; river pollution

\section{Introduction}

The conservation of soil and water resources is a key aspect of the economic and environmental sustainability of all types of agricultural and forestry systems. Recently, Kumar et al. [1] evaluated different soil moisture conservation measures in India (staggered contour trenches, continuous contour trenches, stone mulch, and vegetative barriers) for the reclamation of degraded land and to test their capacity to perform ecological functions and provide economic returns to the farmers. These authors found that horti-pasture systems with Emblica officinalis and Psidium guajava trees and pastures with staggered trenching could enhance income, ensure fodder supply, and improve degraded land. Panagos et al. [2] combined biophysical and macroeconomic models to estimate the cost of agricultural productivity loss due to soil erosion by water in the European Union (EU). The 12 million hectares of agricultural areas in the EU that suffer from severe erosion were estimated to lose around $0.43 \%$ of their crop productivity annually. The annual cost of this loss in agricultural productivity was estimated at around $€ 1.25$ billion.

Soil erosion is one of the main threats to soil and water conservation, and numerous studies have dealt with this topic using field and modelling approaches. Reduced tillage and non-till farming in cereal fields [3] and cover crops in woody crops [4,5], such as vineyards, olive, almond and citrus 
groves, provide environmentally-friendly alternatives (reducing erosion and runoff yield, improving aggregate stability, microporosity, soil water infiltration and storage, fixing atmospheric nitrogen and carbon, reducing nitrogen leaching, improving soil health, etc.) to conventional tillage (several plough passes per year, and the application of herbicides) for land management, as well as to mitigate and adapt to climate change. However, there is debate about the negative effects of plant covers on crops, which is mainly related to water and nutrient competition but also with to diseases, all of which affect crop yield.

Agricultural nutrient balances have been receiving increasing attention in both historical and nutrient management research. In Portugal, Carmo et al. [6] found a consistent deficit in nitrogen (N) both for nationwide $\left(-2.1 \mathrm{~kg} \mathrm{ha}^{-1}\right.$ year $\left.{ }^{-1}\right)$ and arable crops $\left(-1.6 \mathrm{~kg} \mathrm{ha}^{-1}\right.$ year $\left.{ }^{-1}\right)$ estimates in the period 1951-1956, which was rectified at the start of the 1960s. Phosphorous (P) and potassium (K) were, in contrast, accumulated in the soil (4.2-4.6 kg ha ${ }^{-1}$ year ${ }^{-1}$ and $1.0-3.0 \mathrm{~kg} \mathrm{ha}^{-1}$ year ${ }^{-1}$, respectively). These authors observed that the 1950s was the moment of inflection from an agriculture-fertilized system predominantly through reused $\mathrm{N}$ in biomass (livestock excretions plus marine, plant and human waste sources) to one where chemical fertilizers prevailed. It was suggested that $\mathrm{N}$ deficiency played an important role in this transition. On the other hand, pollution processes in agroecosystems with irrigated croplands, including nitrate $\left(\mathrm{NO}_{3}{ }^{-}\right)$, phosphate $\left(\mathrm{PO}_{4}{ }^{3-}\right)$, and total dissolved solids (TDS), present a high degree of variation owing to agricultural management (including crop surfaces, irrigation and fertilization rates) [7].

Hydrologic and geomorphic studies in natural forestry areas and forest plantations are necessary to assess the impact of natural- and human-induced heterogeneities, such as climate variability, vegetation reconstruction, abandoned fields and timber activities, and thus to propose best management practices. Forest management operations in plantation forests, such as landing, tree planting, forest road engineering, thinning, cutting, extraction (harvesting), and transport (skidding trails), modify runoff and sediment yield and downstream environmental issues. For example, Onda et al. [8] observed at catchment- and plot-scales that overland flow decreased about five to ten times with increasing values of understory vegetation density in managed and unmanaged plantations of Japanese cypress (Chamaecyparis obtusa Endl.) and Japanese cedar (Cryptomeria japonica D. Don), as well as in broadleaf forests.

Multi-temporal and inter-disciplinary studies can help to investigate the medium- and long-term consequences of good and bad management practices on soil and water conservation. This Special Issue aims to collect original and quantitative studies dealing with any technique of soil and water conservation. Studies done under any type of climatic (arid, Mediterranean, temperate, tropical and cold) and topographic conditions, land use and management practices were welcome, particularly manuscripts where conservation policies were evaluated. From a total of 14 submitted manuscripts, six articles were accepted for publication; for example, the study by Wang et al. [9], who performed a bibliometric analysis of soil and water conservation in the Loess tableland-gully region of China. This region is one of the main topographic-ecological units in the Chinese Loess Plateau (CLP), where the soil suffers from serious water erosion. In recent years, much work has been conducted to control soil erosion in this area. In this article, Wang et al. [9] summarized the development of soil and water conservation researches in the CLP based on the Science Citation Index (SCI) and Chinese National Knowledge Infrastructure (CNKI) databases. The quantity of SCI literature has increased rapidly since 2007, with an average annual growth rate of $21.4 \%$, and the quantity of CNKI literatures in the last decade accounted for $62 \%$ of the total of the past 30 years. The development trends showed that early SCI research was related to loess geology in the context of ecological remediation, while the CNKI literature focused on agricultural production under comprehensive management. Over time, the research themes of the two databases gradually became unified; i.e., the management of sloping farmland and the improvement of agricultural productivity. Subsequently, the themes gradually extended to the disposition of comprehensive control measures for soil erosion and the environmental effect of agro-fruit ecosystems. According to this study, the highly cited papers mainly focused on soil 
reservoir reconstruction, soil erosion factors, and the environmental effects of vegetation restoration. These authors highlighted that two aspects need further study: (i) the effect of soil erosion control under different ecological remediation patterns, and (ii) the ecosystem maintenance mechanism and regulation approaches that are based on the sustainable utilization of soil and water resources in the tableland-gully region of the Loess Plateau.

\section{Soil and Water Conservation in Farmlands}

\subsection{Soil and Water Conservation in Croplands}

Soil erosion seriously affects vineyards. In a rainfed vineyard formed by four fields and located in NE Spain, Ben-Salem et al. [10] evaluated the influence of two vegetation covers on topsoil moisture and the effect of different physiographic conditions on runoff $(\mathrm{Q})$ and sediment (SY) yields during 15 months. One field had spontaneous vegetation in the inter-row areas, and three fields had a cover crop of common sainfoin (Onobrychis viciifolia). Moisture conditions were dry and stable in the vineyards' rows, wet and very variable in the inter-row areas and wet and very stable in the corridors. Topsoil moisture in the areas with common sainfoin was much higher than in the rows $(62-70 \%)$, whereas this difference was lower with spontaneous vegetation ( $40 \%)$. These authors installed two runoff and sediment traps (STs) in the course of two ephemeral gullies that affected the largest vineyard, and 26 time-integrated surveys (TIS) were performed. The mean runoff yields were 9.8 and $13.5 \mathrm{~L} \mathrm{TIS}^{-1}$ in ST2 and ST3. Cumulative rainfall depth $(\Sigma \mathrm{R}=12 \mathrm{~mm})$ and erosivity $\left(\Sigma \mathrm{EI}_{30}=5.2 \mathrm{MJ} \mathrm{mm} \mathrm{ha}{ }^{-1} \mathrm{~h}^{-1}\right)$ thresholds for runoff initiation were assessed. This threshold was higher than the rainfall threshold (between 4.6 and $8.5 \mathrm{~mm}$ ) observed by Rodrigo-Comino et al. [11] in sloping vineyards in south-eastern Spain under bare soil conditions. Ben-Salem et al. [10] also estimated the $\Sigma \mathrm{R}$ threshold to reach a $\mathrm{Q}>20 \mathrm{~L} \mathrm{TIS}^{-1}$ of ca. $18 \mathrm{~mm}$, and Q $>30 \mathrm{~L} \mathrm{TIS}^{-1}$ was only found with $\Sigma \mathrm{R}>45 \mathrm{~mm}$. The mean turbidity was 333 (ST\#2) and 19 (ST\#3) $\mathrm{g} \mathrm{L}^{-1}$. The results suggested that both contributing areas were activated during the same rainfall-runoff events, and the differences in $Q$ and SY over the test period were explained by (i) the differences in the ground conditions, such as the effective drainage area, the slope gradient and the percentage of soil surface cover; and (ii) the changes in the canopy cover (grapevines and vegetation covers) over the 12 months of the year that were associated with the plants' phenology and the tillage practices. The results of this study are of interest to improve the management and conservation of soil and water in rainfed Mediterranean vineyards, with common sainfoin appearing as an efficient cover crop.

In an alpine pastoral area in the Tibet Autonomous Region, Southwestern China, Sun et al. [12] evaluated the processes of soil water depletion in planted alfalfa pastures. Alfalfa (Medicago sativa) has strong stress resistance, high nutritional value, good palatability for cattle, high yield, and a drought tolerance mechanism, but long-term planting leads to soil desiccation. This research was carried out to examine the soil water conditions of alfalfa pastures with different plant ages and determine the optimum time for alfalfa rotation in a plateau area with a sub-alpine monsoon climate (an average annual temperature of $8.2^{\circ} \mathrm{C}$ and precipitation of $641 \mathrm{~mm} \mathrm{year}^{-1}$ ). Soil water depletion, soil compaction and vegetation characteristics of alfalfa pastures of different ages (i.e., two, four and seven years) were assayed and compared with those of a cornfield which served as the control crop. These authors used three $20 \times 20 \mathrm{~m}$ plots, and five random quadrats per plot were established at each field. Soil water contents at $0-400 \mathrm{~cm}$ soil depth and plant biomass were compared among the different vegetation types, soil transects, and age of the plantation. The results showed that at the $250-400 \mathrm{~cm}$ depth, the soil water storage of the four- and seven-year-old alfalfa pastures was much lower than in the two-year-old alfalfa pasture and in the cornfield. Moreover, the degree of the soil water storage deficit of the four- and seven-year-old pastures was much higher than in the other fields. Soil compaction of alfalfa pastures increased with increasing plant age and reached a peak value in the seven-year-old pasture. The highest above-ground biomass was observed in the four-year-old alpine alfalfa pasture. Thus, the best cultivation period for alfalfa pastures was four years from the perspective of higher 
yield and lower soil water consumption in pastoral sub-alpine areas. This study provided a basis for sustainable alfalfa pasture cultivation, timely harvest, rotation and water management measures to be implemented in alpine grazing lands.

\subsection{Soil and Water Conservation in Forest Plantations}

Sustainable forest management requires a clear understanding of the changes in soil quality owing to human activities. Zhang et al. [13] evaluated the effects of afforestation on soil bulk density (BD) and $\mathrm{pH}$ in the Loess Plateau, China. These authors explored whether afforestation had the potential to improve the soil quality by comparing five treatments: three forested treatments (16-and 40-year-old apricot stands, and 40-year-old poplar stands), with individual abandoned and cultivated treatments serving as the controls. This study highlighted that BD values across the $0-1.0 \mathrm{~m}$ soil profile under the 16-year-old apricot treatment $\left(1.12 \mathrm{Mg} \mathrm{m}^{-3}\right)$ and 40 -year-old poplar treatment $\left(1.16 \mathrm{Mg} \mathrm{m}^{-3}\right)$ were significantly smaller than their counterparts under the cultivated $\left(1.20 \mathrm{Mg} \mathrm{m}^{-3}\right)$ and abandoned treatments $\left(1.23 \mathrm{Mg} \mathrm{m}^{-3}\right)$. The soil $\mathrm{pH}$ of the cultivated treatment (8.46) was significantly lower than that of the abandoned treatment (8.51) or of any forested treatment. The $\mathrm{BD}$ and $\mathrm{pH}$ were both affected by stand age, with the $\mathrm{BD}$ and $\mathrm{pH}$ of the 40 -year-old apricot treatment being $0.10 \mathrm{Mg} \mathrm{m}^{-3}$ and 0.05 units greater, respectively, than those of the 16-year-old apricot treatment. Treatment and soil depth appeared to interact to influence the $\mathrm{BD}$, but this same interaction did not influence the soil $\mathrm{pH}$. This study suggested that afforestation species and stand age should be taken into consideration to harvest maximum benefits from the afforestation efforts.

\section{Land Uses, Tillage Practices and Water Quality}

The understanding of soil-water dynamics is essential to prevent collateral impacts in sub-superficial waters by leached pollutants and to implement suitable soil management (e.g., agronomic measures to avoid nitrate leaching). Rainfed Mediterranean agriculture is characterized by a low water input and by a soil water content below its field capacity during most of the year. However, erratic rainfall distribution can lead to deep drainage. In a rainfed semiarid Mediterranean agricultural system, Jiménez-de-Santiago et al. [14] evaluated soil water dynamics during two fallow years and three barley crop seasons using the leaching estimation and chemistry model. Model calibration was carried out using soil moisture data from disturbed soil samples and from capacitance probes installed at three depths. Drainage of water from the plots occurred in the fall and winter periods. The yearly low drainage values obtained $(<15 \mathrm{~mm})$ indicated that the estimated annual nitrate leaching was also small, regardless of the nature of the fertilizer applied (slurries or minerals). In fallow periods, there was a water recharge in the soil, which did not occur under barley cropping. The authors of this study concluded that annual fallow included in a winter cereal rotation, high nitrate residual soil concentrations $\left(\sim 80 \mathrm{mg} \mathrm{NO}^{3-}-\mathrm{N} \mathrm{L}^{-1}\right)$ and a period with substantial autumn-winter rains $(70-90 \mathrm{~mm}$ ) could enhance nitrate leaching, despite the semiarid (a mean annual temperature of $12.6^{\circ} \mathrm{C}$ and annual precipitation of $443 \mathrm{~mm}$ ) climate.

Due to an increase in poorly planned anthropogenic activities, the water quality of several large Asian rivers is being severely affected. Although the assessment of heavy metal contents is vital to develop and design sustainable water management plans, several areas in Central Asia such as Kazakhstan do not have recent studies available that evaluate this situation. Yegemova et al. [15] identified the key information and land management plans for water conservation under dry weather conditions in the border areas of the Syr Darya River in Kazakhstan. These authors carried out the first approach to a water quality assessment in Kazakhstan's Syr Darya River, where a massive expansion of irrigation canals, pastures in middle- and lower-reaches and an increase in industrialization and population have lowered its potential water capacity. To achieve this goal, various physicochemical parameters were analysed (using a Multi N/C $2100 \mathrm{~S}$ analyser, and an atomic absorption spectrometer) for 43 water samples along the river under dry weather conditions at $25 \mathrm{~cm}$ water depth. In the cluster analysis, five cluster groups were obtained, and the first cluster consisted of the highest number of 
water sampling points (eight). The last cluster was made up of only one point, which showed the highest difference against the other sites in our model. The non-metric multidimensional scaling method also confirmed that some specific points along the river were different. Five components were extracted from the principal component analysis: (1) COD (chemical oxygen demand), $\mathrm{Zn}, \mathrm{Cu}, \mathrm{Pb}, \mathrm{Ni}$ and $\mathrm{Mn}$; (2) $\mathrm{Cu}, \mathrm{Cd}, \mathrm{Ni}$ and $\mathrm{Co}$; (3) $\mathrm{T}$ (water temperature), $\mathrm{pH}$ and $\mathrm{DO}$ (dissolved oxygen); (4) $\mathrm{T}$ and $\mathrm{Fe}$; and (5) COD and OC (organic carbon). The heavy metal pollution index showed very high values (279.9), which were locally confirmed in some hotspots close to the Aral Sea, industrialized areas and agricultural fields. The findings of this study demonstrated that, under dry weather conditions, surface water resources could be mismanaged in the Syr Darya River in Kazakhstan in specific areas. Regarding future work, considering the important role that agriculture and pasture play in the Kazakh economy, the authors insisted upon the importance of applying water-quality control measures, nature-based solutions, and efficient management plans. The authors highlighted the necessity of conducting further research related to sampling under other weather situations such as wet and cold conditions, different river water depths, and other locations considering specific land uses; for example, grazing, mining, railways or industries.

\section{Conclusions}

At present, soil and water conservation studies are receiving a great deal of attention from a variety of sectors, such as the scientific community, policy makers, ecological organizations, media and society. In academia, the highly cited papers are mainly focused on soil reservoir reconstruction, soil erosion factors, and the environmental effects of vegetation restoration, whereas two aspects need further study: (i) the effect of soil erosion control under different ecological remediation patterns, and (ii) the ecosystem maintenance mechanism and regulation approaches. The set of tillage practices and management strategies that favor soil and water conservation vary as a function of the main land use, such as cropland, forest, or rivers, and of the country where these practices are used. The use of cover crops in woody crops, such as vineyards, allows the reduction of runoff and sediment yield, and these effects are higher than those obtained with spontaneous vegetation. In alpine grazing lands, the best cultivation period with alfalfa pastures appears in the seven-year-old pastures owing to the evolution in the biomass production and soil water storage deficit.

Global climate changes, land degradation, soil and water pollution, irregular fresh-water availability, and food security are serious challenges that are currently threatening the environmental, economic and social sustainability of many regions around the world. Afforestation has the potential to improve soil quality, although tree species and stand age should be taken into consideration to obtain maximum benefits because these factors determine the changes of soil bulk density and $\mathrm{pH}$. Hence, proper use of soil and water resources is necessary to ensure and advance the future well-being of humans and of the environment. Fallow-crop rotation is a common practice in semi-arid areas that affects soil water recharge and nitrate leaching (pollutant delivery) in fields with annual crops, in particular during the autumn-winter rains. At the river basin scale, such as in the Syr Darya River in Kazakhstan, water resource mismanagement has given rise to heavy metal pollution in specific areas. Therefore, local and national legislation, including subsidies and regulations, have a critical role to play to boost effective and environmental-friendly management strategies.

Author Contributions: M.L.-V. and G.-L.W. equally contributed to the different activities conducted in this special issue.

Funding: This research was funded by the Spanish Ministry of Economy and Competitiveness (CGL2014-54877-JIN), by the National Natural Science Foundation of China (NSFC41722107, 31372368), and the Light of West China Program (XAB2015A04).

Acknowledgments: We thank all of the Assistant Editors of Water, for their accessibility and timely work during the development of this Special Issue.

Conflicts of Interest: The authors declare no conflict of interest. 


\section{References}

1. Kumar, S.; Singh, A.K.; Singh, R.; Ghosh, A.; Chaudhary, M.; Shukla, A.K.; Kumar, S.; Singh, H.V.; Ahmed, A.; Kumar, R.V. Degraded land restoration ecological way through horti-pasture systems and soil moisture conservation to sustain productive economic viability. Land Degrad. Dev. 2019, 30, 1516-1529. [CrossRef]

2. Panagos, P.; Standardi, G.; Borrelli, P.; Lugato, E.; Montanarella, L.; Bosello, F. Cost of agricultural productivity loss due to soil erosion in the European Union: From direct cost evaluation approaches to the use of macroeconomic models. Land Degrad. Dev. 2018, 29, 471-484. [CrossRef]

3. Borrelli, P.; Paustian, K.; Panagos, P.; Jones, A.; Schütt, B.; Lugato, E. Effect of good agricultural and environmental conditions on erosion and soil organic carbon balance: A national case study. Land Use Policy 2016, 50, 408-421. [CrossRef]

4. Kaye, J.P.; Quemada, M. Using cover crops to mitigate and adapt to climate change. A review. Agron. Sustain. Dev. 2017, 37, 4. [CrossRef]

5. Sastre, B.; Marques, M.J.; García-Díaz, A.; Bienes, R. Three years of management with cover crops protecting sloping olive groves soils, carbon and water effects on gypsiferous soil. Catena 2018, 171, 115-124. [CrossRef]

6. Carmo, M.; García-Ruiz, R.; Ferreira, M.I.; Domingos, T. The N-P-K soil nutrient balance of Portuguese cropland in the 1950s: The transition from organic to chemical fertilization. Sci. Rep. 2017, 7, 8111. [CrossRef] [PubMed]

7. Merchán, D.; Casalí, J.; Del Valle de Lersundi, J.; Campo-Bescós, M.A.; Giménez, R.; Preciado, B.; Lafarga, A. Runoff, nutrients, sediment and salt yields in an irrigated watershed in southern Navarre (Spain). Agric. Water Manag. 2018, 195, 120-132. [CrossRef]

8. Onda, Y.; Gomi, T.; Mizugaki, S.; Nonoda, T.; Sidle, R.C. An overview of the field and modelling studies on the effects of forest devastation on flooding and environmental issues. Hydrol. Process. 2010, 24, 527-534. [CrossRef]

9. Wang, Y.; Liu, W.; Li, G.; Yan, W.; Gao, G. A bibliometric analysis of soil and water conservation in the Loess tableland-gully region of China. Water 2019, 11, 20. [CrossRef]

10. Ben-Salem, N.; Álvarez, S.; López-Vicente, M. Soil and water conservation in rainfed vineyards with common sainfoin and spontaneous vegetation under different ground conditions. Water 2018, 10, 1058. [CrossRef]

11. Rodrigo-Comino, J.; Senciales, J.M.; Ramos, M.C.; Martínez-Casasnovas, J.A.; Lasanta, T.; Brevik, E.C.; Ries, J.B.; Ruiz-Sinoga, J.D. Understanding soil erosion processes in Mediterranean sloping vineyards (Montes de Málaga, Spain). Geoderma 2017, 296, 47-59. [CrossRef]

12. Sun, L.; Huang, Z.; Cui, Z.; Lu, R.; Zhang, R.Q.; Liu, Y.; López-Vicente, M.; Ahirwal, J.; Wei, X.H.; Wu, G.L. Soil water depletion in planted alfalfa pastures in an alpine pastoral area. Water 2018, 10, 1538. [CrossRef]

13. Zhang, X.; Adamowski, J.F.; Deo, R.C.; Xu, X.; Zhu, G.; Cao, J. Effects of afforestation on soil bulk density and $\mathrm{pH}$ in the Loess Plateau, China. Water 2018, 10, 1710. [CrossRef]

14. Jiménez-de-Santiago, D.E.; Lidón, A.; Bosch-Serra, A.D. Soil water dynamics in a rainfed Mediterranean agricultural system. Water 2019, 11, 799. [CrossRef]

15. Yegemova, S.; Kumar, R.; Abuduwaili, J.; Ma, L.; Samat, A.; Issanova, G.; Ge, Y.; Kumar, V.; Keshavarzi, A.; Rodrigo-Comino, J. Identifying the key information and land management plans for water conservation under dry weather conditions in the Border areas of the Syr Darya River in Kazakhstan. Water 2018, 10, 1754. [CrossRef]

(C) 2019 by the authors. Licensee MDPI, Basel, Switzerland. This article is an open access article distributed under the terms and conditions of the Creative Commons Attribution (CC BY) license (http://creativecommons.org/licenses/by/4.0/). 